\title{
Prevention of browning reaction in banana jam during storage by physical and chemical treatments
}

\author{
Aimi Azira, S., *Wan Zunairah, W.I., Nor Afizah, M., Nor-Khaizura, M.A.R., Radhiah, S., \\ Ismail Fitry, M.R. and Nur Hanani, Z.A.
}

Faculty of Food Science and Technology, Universiti Putra Malaysia, 43400 Sri Kembangan, Selangor, Malaysia

\author{
Article history: \\ Received: 20 January 2021 \\ Received in revised form: 23 \\ February 2021 \\ Accepted: 13 April 2021 \\ Available Online: 10 \\ September 2021

\section{Keywords:} \\ Banana jam, \\ Ascorbic acid, \\ Sodium metabisulphite, \\ Browning reaction, \\ Storage

\section{DOI:} \\ https://doi.org/10.26656/fr.2017.5(5).046
}

\begin{abstract}
Bananas are fruits that quickly turn brown after being peeled or cooked. The browning reaction reduces the quality of the appearance and shelf life of banana jam. Therefore, this study was aimed to evaluate the effect of chemical blanching and anti-browning agents on reducing browning reactions and maintaining the quality of banana jam during storage. In this study, Musa paradisiaca cv. Nipah was used to produce banana jam. The banana jam was prepared using three different treatments. The first treatment was prepared without hot water blanching treatment and with the addition of ascorbic acid and sodium metabisulphite. The jam was prepared with banana pulp, sugar, citric acid, and pectin. This treatment act as a control. The banana jam for the second and third treatments was prepared using the same ingredients as treatment one. In the second treatment, the sliced banana was blanched in hot water $\left(80^{\circ} \mathrm{C}\right)$ for 10 mins, whereas in treatment three, the banana slices were dipped into $1.5 \%$ of ascorbic acid solution at $80^{\circ} \mathrm{C}$ for 10 mins. During the cooking process, $0.1 \%$ of sodium metabisulphite was added into the jam, for treatments two and three. The jam was cooked until the temperature reached $105^{\circ} \mathrm{C}$ and the total soluble solids range from $68-70^{\circ} \mathrm{Bx}$. The banana jam was filled in glass jars, sterilized in a hot water bath at $80^{\circ} \mathrm{C}$ for $10 \mathrm{mins}$, cooled to $27^{\circ} \mathrm{C}$ (room temperature) before being stored at room temperature. The analysis observed were $\mathrm{pH}$, total soluble solids, titrable acidity, colour, browning index, and textural properties. The samples were stored at room temperature for 60 days. The observations were made every 15 days for two months. After 60 days of storage, all treatments showed positive changes and a significant difference $(\mathrm{p}<0.05)$ in physicochemical and texture analyses. Overall, hot water blanching and chemical treatments significantly reduced the browning reaction in the banana jam. Therefore, treatment three had the best ability to slow down the browning reaction and deterioration rate of banana jam during room temperature storage.
\end{abstract}

\section{Introduction}

Jam has a suitable gelled consistency, made from fruit pulp or fruit puree or both, of one or more kinds of fruit, which is mixed with sugars or other carbohydrate sweeteners such as honey, and boiled with or without the addition of water, pectin and acid (Codex Alimentarius Commission, 2004; Ngoh et al., 2018). Jam production is the act of fruit preservation process to stop or slow down fruit spoilage, quality and nutritional value loss, edibility and extend the shelf life of the fruit storage (Darkwa et al., 2016). Many types of fruit jam can be found in the market, such as strawberry jam, blueberry jam, mango jam, pineapple jam, and others. However, there is no banana jam in the market due to the difficulty in controlling the browning reaction during processing and storage.

Bananas undergo rapid enzymatic browning after exposure to oxygen due to disruption of fruit tissue during peeling, cutting and pulping operations (Wang et al., 2013). Wang et al. (2013) also reported that the browning reactions occur mainly cause by polyphenol oxidase (PPO). The hydroxylation of monophenols to diphenols that catalyzed by polyphenol oxidase, produces quinones. The quinones undergo polymerization and produce polyphenols (black, brown or red pigments) which lead to the browning reaction in fruits and vegetables (Arpita et al., 2010). Dopamine is defined as the crucial and the most reactive substrate for 
banana's PPO (Danyen et al., 2008). These reactions affect colour, flavour, and nutritional value. Martínez et al. (2012) reported that the rate of enzymatic browning is determined by the tissue's active PPO content, the tissue's phenolic content and the availability of $\mathrm{pH}$, temperature and oxygen in the tissue.

The browning reaction could be slowed down or stopped by inactivating the enzyme with specific methods such as heat, reducing the $\mathrm{pH}$ on the fruit surface (applying lemon juice or other acids), reducing the amount of oxygen available (placing cut fruit underwater or storing it in a vacuum) or adding other preservative chemicals such as sulfur dioxide (Yildiz, 2018). Based on previous studies, there were several concerns in the production of mixed fruit jam, such as to produce a jam with health beneficial aspects (Ahmed et al., 2015), good sensory properties and create the prospect of larger consumer space (de Souza Viana et al., 2014; Muresan et al., 2014). Patel et al. (2015) studied the quality and effect of banana-pineapple blended jam. The authors concluded that mixed fruits jam had better flavour and texture and were able to attract consumers. There are limited studies on producing banana jam without the mixture of other fruits, due to the browning reaction that easily occurs to the banana pulp during processing and storage. As browning easily occurs for banana products, most of the previous studies used banana pulp mixed with other fruits to produce mixed fruit jam.

In this study, the banana jam was made up of banana fruit without a mixture of other fruits to determine a suitable method to reduce the browning effect and maintain the quality of the jam during storage. Therefore, the objective of this study is to evaluate the effect of physical (hot water blanching) and chemical (ascorbic acid and sodium metabisulphite) treatments on reducing browning reaction and maintaining the quality of banana jam during storage.

\section{Materials and methods}

\subsection{Materials}

The raw material was fully ripened Nipah bananas obtained from a local farmer at Kuala Pilah, Negeri Sembilan. A pH meter, refractometer, texture analyser, and chromameter were used in this study. The reagents used included ascorbic acid, sodium metabisulphite, sodium hydroxide $(\mathrm{NaOH})$, and phenolphthalein.

\subsection{Physical and chemical treatment}

Three treatments were prepared with three replications. The first treatment was the banana jam was prepared without hot water blanching treatment and addition of ascorbic acid and sodium metabisulphite. The jam is prepared with banana pulp, sugar, citric acid, and pectin. This treatment acts as a control. The banana jam for the second and third treatments was prepared by using the same ingredients as treatment one. In the second treatment, the sliced banana was blanched in hot water $\left(80^{\circ} \mathrm{C}\right)$ for 10 mins, whereas in treatment three, the banana slices were dipped into $1.5 \%$ of ascorbic acid solution at $80^{\circ} \mathrm{C}$ for 10 mins. During the cooking process, $0.1 \%$ of sodium metabisulphite was added into the jam, for treatments two and three.

\subsection{Banana jam formulation}

Jam components are in ratios 50: 50 of fruit pulp: sugar respectively. The formulation and preparation of jam were obtained from the Food and Agriculture Organization (FAO, 2019). The formulation consists of $1000 \mathrm{~g}$ of banana pulp with total soluble solid at $10 \%$ and $1000 \mathrm{~g}$ of sugar. Other ingredients were $6 \mathrm{~g}$ of pectin (grade 200) and $5.5 \mathrm{~g}$ of citric acid.

\subsection{Banana jam preparation}

The untreated and treated sliced banana and sugar were placed into the different stainless-steel steam jacketed kettle and heated to about $43 \mathrm{C}$ with continuous stirring. Then, the heat was turned off and the pectin was added into the mixture and stirred continuously. Once the pectin and the remaining sugar were dissolved, the heat was turned on again and the mixture was stirred until it boiled vigorously. The mixture was stirred until the temperature reached almost $105^{\circ} \mathrm{C}$. Then, citric acid was added and stirred until the temperature reached $105^{\circ}$ C. The total soluble solids of the jam were measured until they reached the required point of more than $68^{\circ} \mathrm{Bx}$. The banana jam was filled into the glass jars and close, then immediately inverted to pasteurize for three mins. The banana jam was cooled and stored at room temperature for 60 days.

\subsection{Quality evaluation of banana jam}

2.5.1 Determination of $\mathrm{pH}$, titrable acidity, and total soluble solids

The $\mathrm{pH}$ was determined by homogenizing $5 \mathrm{~g}$ of the jam with $40 \mathrm{~mL}$ of distilled water. The $\mathrm{pH}$ was determined by using a $\mathrm{pH}$ meter, Jenway Model 3505 (United Kingdom) with the calibration buffer at $\mathrm{pH} 4.0$ and pH 7.0 (Kheng et al., 2012). The acidity of the jam was observed by using the titration method. The jam (6 g) was mixed with $50 \mathrm{~mL}$ of distilled water. The mixture $(10 \mathrm{~mL})$ was placed into a different beaker with three drops of phenolphthalein. A concentration of $0.1 \mathrm{~N}$ of $\mathrm{NaOH}$ was used to titrate the solution until it reached $\mathrm{pH}$ 8.2 and the volume of $\mathrm{NaOH}$ was recorded. The total titrable acidity was calculated by using the formula 
below and express in the percentage of malic acid, referring to Ngoh et al. (2018). The total soluble solids were measured by using a digital refractometer (ATAGO, Tokyo, Japan). Approximately, $1 \mathrm{~g}$ of the jam was placed onto the glass prism of the refractometer and the reading was recorded as ${ }^{\circ} \mathrm{Bx}$, based on the method by Yap et al. (2017).

Percentage of malic acid:

$\%$ malic acid $=\frac{\mathrm{mL} \text { of } \mathrm{NaOH} \text { used } \times 0.1 \mathrm{~N} \mathrm{NaOH} \times \text { milliequivalent factor }(0.067) \times 100}{\text { grams of sample }}$

\subsubsection{Determination of colour}

The measurement of upper surface colour was carried out by using a Chroma Meter CR-400, Konica Minolta (Singapore). The result was expressed as CIE $\left(L^{*}, a^{*}, b^{*}\right)$ system, which represents lightness, redness and yellowness respectively (Banaś et al., 2018). The browning index assessment was calculated by using the formula as follows (Ding and Ling, 2014):

$$
B I=\frac{100(x-0.31)}{0.17}
$$

Where $\mathrm{x}=\left(\mathrm{a}^{*}+1.75 \mathrm{~L}^{*}\right) /\left(5.645 \mathrm{~L}^{*}+\mathrm{a}^{*}-0.3012 \mathrm{~b}^{*}\right)$

\subsubsection{Determination of textural properties}

The textural properties measured included firmness, work of shear, stickiness, and work of adhesion. The probe used was $45^{\circ}$ angle perspex conical probe with the test speed at $3 \mathrm{~mm} / \mathrm{s}$, the post-test speed at $10 \mathrm{~mm} / \mathrm{s}$, distance at $30 \mathrm{~mm}$, and trigger type button with $5 \mathrm{~kg}$ load cell. The height calibration was performed with $30 \mathrm{~mm}$ of return distance, $20 \mathrm{~g}$ of return force and $20 \mathrm{~mm} / \mathrm{s}$ of return speed (Basu and Shivhare, 2010).

\subsection{Statistical analysis}

The data were analyzed by using One-Way Analysis of Variance (ANOVA), significance difference was compared by using the Tukey test, with a significant level $\mathrm{P}<0.05$. The statistical was performed using Minitab software, version 19.

\section{Results and discussion}

\section{$3.1 \mathrm{pH}$}

The $\mathrm{pH}$ values of the banana jam for all treatments on the initial day were ranged from 4.40, 4.04, and 3.96, respectively (Table 1). The $\mathrm{pH}$ value of the jam for treatment one on the initial day was 4.40 and significantly decreased to 4.28 on the final day, whereas the $\mathrm{pH}$ value for treatment two and three on the initial day were 4.04 and 3.96 , then significantly lowered to 3.79 and 3.73 , respectively. The maximum value for $\mathrm{pH}$ was shown on the initial day for treatment one which is 4.40 , and the minimum value of the jam was observed on the final day of storage for treatment three, which was 3.73. The different values of the $\mathrm{pH}$ for all treatments might be due to the addition of ascorbic acid and sodium metabisulphite.

The observed data were compared with the findings of Ehsan et al. (2002), where the $\mathrm{pH}$ value of watermelon and lemon blended jam decreased during storage. Shakir (2008) have proven that the apple and pear mixed fruit jam showed a decreasing $\mathrm{pH}$ value during storage. Another study from Rababah et al. (2010), also reported the $\mathrm{pH}$ value for cherry jam, apricot jam, fig jam, and orange jam were decreased during the storage period. According to Rababah et al. (2010), the formation of hydroxymethylfurfural (HMF) during processing and storage by hydration of sugar caused the reduction of the $\mathrm{pH}$ value of the fruit jam. The hydration of sugar leads to the conversion of the HMF into levulinic and formic acid. In contrast, Ahmed et al. (2015) observed decreasing $\mathrm{pH}$ value in the banana mushroom blended jam. The reduction of the $\mathrm{pH}$ value during storage might be due to the acidic compound formation (Ayub et al., 2010; Hussain and Shakir, 2010). The $\mathrm{pH}$ is the main factor in obtaining the best gel condition in a jam (Ahmed et al., 2015).

\subsection{Titrable acidity}

The acidity of banana jam for all treatments on the initial day ranged from 0.063 to $0.083 \%$. The acidity of banana jam for treatment one increased from 0.063 to $0.093 \%$, while for treatment two, the initial value of acidity was $0.082 \%$ and increased to $0.105 \%$. The acidity of jam for treatment three for the initial day was $0.063 \%$ and increased to $0.097 \%$ along storage time. The maximum value for treatment was observed for treatment two $(0.105 \%)$, while the minimum value was observed for treatment one $(0.063 \%)$. However, the increasing trend for all treatments are were not statistically significant (Table 1).

Despite that, based on the previous studies, mostly the acidity of the jam increased during storage time. The findings from Khan et al. (2012) showed that the acidity of strawberry jam increased from 0.68 to $0.86 \%$ during storage. Ashaye and Adeleke (2009) also reported an increase in the acidity of stored roselle jam. The increasing acidity in the jam during storage may be due to several reasons, such as the presence of acidophiles and the formation of different organic acids throughout carbohydrates degradation and hydrolysis (Ashaye and Adeleke, 2009; Shah et al., 2015). The acidity preserved the jam from microorganism's growth for a long period of time (Touati et al., 2014). The difference in the results might be due to the different fruits used, formulations, preparations, methods, and storage time. 
Table 1. Average of physicochemical ( $\mathrm{pH}$, titrable acidity, total soluble solids, browning index) parameters of banana jam during storage

\begin{tabular}{|c|c|c|c|c|c|}
\hline Day & 1 & 15 & 30 & 45 & 60 \\
\hline \multicolumn{6}{|c|}{$\mathrm{pH}$} \\
\hline Treatment 1 & $4.40 \pm 0.006^{\mathrm{Aa}}$ & $4.38 \pm 0.012^{\mathrm{Ab}}$ & $4.34 \pm 0.006^{\mathrm{Ac}}$ & $4.31 \pm 0.006^{\mathrm{Ad}}$ & $4.28 \pm 0.010^{\mathrm{Ae}}$ \\
\hline Treatment 2 & $4.04 \pm 0.010^{\mathrm{Ba}}$ & $3.96 \pm 0.006^{\mathrm{Bb}}$ & $3.93 \pm 0.015^{\mathrm{Bbc}}$ & $3.92 \pm 0.010^{\mathrm{Bc}}$ & $3.79 \pm 0.010^{\mathrm{Bd}}$ \\
\hline Treatment 3 & $3.96 \pm 0.006^{\mathrm{Ca}}$ & $3.85 \pm 0.015^{\mathrm{Cb}}$ & $3.78 \pm 0.006^{\mathrm{Cc}}$ & $3.73 \pm 0.012^{\mathrm{Cd}}$ & $3.73 \pm 0.006^{\mathrm{Cd}}$ \\
\hline \multicolumn{6}{|c|}{ Titratable acidity (\% malic acid) } \\
\hline Treatment 1 & $0.063 \pm 0.013^{\mathrm{Aa}}$ & $0.067 \pm 0.012^{\mathrm{Aa}}$ & $0.074 \pm 0.017^{\mathrm{Aa}}$ & $0.085 \pm 0.006^{\mathrm{Aa}}$ & $0.093 \pm 0.007^{\mathrm{Aa}}$ \\
\hline Treatment 2 & $0.082 \pm 0.017^{\mathrm{Aa}}$ & $0.085 \pm 0.006^{\mathrm{Aa}}$ & $0.093 \pm 0.007^{\mathrm{Aa}}$ & $0.097 \pm 0.007^{\mathrm{Aa}}$ & $0.105 \pm 0.006^{\mathrm{Aa}}$ \\
\hline Treatment 3 & $0.063 \pm 0.006^{\mathrm{Ab}}$ & $0.082 \pm 0.017^{\mathrm{Aab}}$ & $0.089 \pm 0.012^{\text {Aab }}$ & $0.093 \pm 0.007^{\mathrm{Aa}}$ & $0.097 \pm 0.007^{\mathrm{Aa}}$ \\
\hline \multicolumn{6}{|c|}{ Total soluble solids $\left({ }^{\circ} \mathrm{Bx}\right)$} \\
\hline Treatment 1 & $71.30 \pm 0.300^{\mathrm{Ad}}$ & $72.30 \pm 0.200^{\mathrm{Ac}}$ & $73.23 \pm 0.306^{\mathrm{Ab}}$ & $73.77 \pm 0.153^{\mathrm{Ab}}$ & $74.87 \pm 0.153^{\mathrm{Aa}}$ \\
\hline Treatment 2 & $71.33 \pm 0.060^{\mathrm{Ac}}$ & $72.40 \pm 0.100^{\mathrm{Ab}}$ & $72.50 \pm 0.265^{\mathrm{Bb}}$ & $72.63 \pm 0.208^{\mathrm{Bb}}$ & $73.77 \pm 0.058^{\mathrm{Ba}}$ \\
\hline Treatment 3 & $71.30 \pm 0.200^{\mathrm{Ab}}$ & $71.40 \pm 0.100^{\mathrm{Bb}}$ & $72.43 \pm 0.058^{\mathrm{Ba}}$ & $72.53 \pm 0.153^{\mathrm{Ba}}$ & $72.63 \pm 0.115^{\mathrm{Ca}}$ \\
\hline \multicolumn{6}{|c|}{ Browning index } \\
\hline Treatment 1 & $14.97 \pm 0.061^{\mathrm{Aa}}$ & $13.87 \pm 0.187^{\mathrm{Ab}}$ & $13.89 \pm 0.103^{\mathrm{Ab}}$ & $12.72 \pm 0.205^{\mathrm{Ac}}$ & $12.14 \pm 0.11^{\mathrm{Ba}}$ \\
\hline Treatment 2 & $15.09 \pm 0.205^{\mathrm{Aa}}$ & $14.34 \pm 0.050^{\mathrm{Ab}}$ & $14.19 \pm 0.406^{\mathrm{Ab}}$ & $13.24 \pm 0.340^{\mathrm{Ac}}$ & $12.99 \pm 0.036^{\mathrm{Ac}}$ \\
\hline Treatment 3 & $12.35 \pm 0.096^{\mathrm{Ba}}$ & $11.87 \pm 0.408^{\mathrm{Ba}}$ & $11.73 \pm 0.351^{\mathrm{Ba}}$ & $11.71 \pm 0.273^{\mathrm{Ba}}$ & $11.67 \pm 0.121^{\mathrm{Ca}}$ \\
\hline
\end{tabular}

Values are presented as mean \pm standard deviation. Values with lowercase superscript within the same row indicate significant difference at $\mathrm{P}<0.05$ while values with uppercase superscript within the same column indicate significant difference at $\mathrm{P}<0.05$.

\subsection{Total soluble solids}

The total soluble solids of banana jam during storage increased significantly $(\mathrm{P}<0.05)$ for all treatments. Based on Table 1, the total soluble solids value of banana jam increased consistently during storage time. The initial value of the total soluble solids of jam for treatment one, two, and three were 71.30, 71.33, and $71.30{ }^{\circ} \mathrm{Bx}$ respectively. The total soluble solids increased until the final day of storage ranged from $72.63^{\circ} \mathrm{Bx}$ (treatment three), $73.77^{\circ} \mathrm{Bx}$ (treatment two), and $74,87^{\circ} \mathrm{Bx}$ (treatment one). The maximum value of total soluble solids was recorded for treatment one $\left(74.87^{\circ} \mathrm{Bx}\right)$ and the minimum value was recorded for treatment three $\left(72.63^{\circ}\right.$ $\mathrm{Bx})$. The difference in total soluble solids value between treatment three and other treatments might be due to the addition of ascorbic acid during the blanching process of banana slices for treatment three.

The results of this study were similar to the findings of Khan et al. (2014) that observed the increase of total soluble solids value in the strawberry jam during storage. Another study done by Pavlova et al. (2013) showed an increase of total soluble solids value of raspberry and peach jam after storage for 15 and 30 days. Kanwale et al. (2017) also found similar findings of the total soluble solids of guava jam increased during storage. The increasing of total soluble solids value in a jam may be due to the solubilization of the ingredients or components and acid hydrolysis of polysaccharides (pectin and gums), reported by Kanwale et al. (2017). Also, sugar and water loss during the boiling process leads to increased total soluble solids of jam (Aksay et al., 2018). Sawant and Patil (2013) suggested that the degradation of pectin and enzymatic conversion of monosaccharides into sugar molecules developed in an increase of total soluble solids. The total soluble solids of the jam should be not less than 68\% (Makanjuola and Alokun, 2019). Sugar is an essential ingredient in preparing jam that improves the appearance (shine and colour) and makes gelation of pectin in a jam (Makanjuola and Alokun, 2019). A high value of total soluble solids can reduce the jam's water activity and prevent microbial and biochemical deterioration (Aksay et al., 2018).

\subsection{Colour}

The colour of banana jam is one crucial factor to determine the quality of the jam. It is also the main component to attract consumers in the market. Based on the results observed (Table 2 ), the $a^{*}$ and $b^{*}$ value decreased significantly during storage. The decreased value of $a^{*}$ and $b^{*}$ indicated that the redness $\left(a^{*}\right)$ and yellowness $\left(b^{*}\right)$ of the banana jam increased, leading to darker colour during the storage time. The $\mathrm{L}^{*}$ indicates the lightness of the colour for banana jam. The L*, a*, and $b^{*}$ decreased gradually during storage. The $L^{*}$ value of treatment three was the highest, 62.86 on the initial day and 55.44 on the final day of storage. This result indicates that the colour of jam for treatment three was brighter than treatment one and treatment two.

Similar findings were reported by Aslanova et al. (2010), the colour ( $\left.\mathrm{L}^{*}, \mathrm{a}^{*}, \mathrm{~b}^{*}\right)$ of the strawberry and apricot jam were decreased during storage. The 
Table 2. Colour $\left(\mathrm{L}^{*}, \mathrm{a}^{*}, \mathrm{~b}^{*}\right)$ of banana jam during storage

\begin{tabular}{cccccc}
\hline Day & 1 & 15 & 30 & 45 & 60 \\
\hline Treatment 1 & $54.25 \pm 0.047^{\mathrm{Ca}}$ & $53.53 \pm 0.310^{\mathrm{Cab}}$ & $52.61 \pm 0.087^{\mathrm{Bbc}}$ & $52.28 \pm 0.530^{\mathrm{Cc}}$ & $50.48 \pm 0.796^{\mathrm{Bd}}$ \\
Treatment 2 & $57.03 \pm 0.556^{\mathrm{Ba}}$ & $55.55 \pm 0.346^{\mathrm{Bb}}$ & $54.99 \pm 0.745^{\mathrm{Bb}}$ & $54.16 \pm 0.491^{\mathrm{Bb}}$ & $52.04 \pm 0.423^{\mathrm{Bc}}$ \\
Treatment 3 & $62.86 \pm 0.116^{\mathrm{Aa}}$ & $62.53 \pm 0.277^{\mathrm{Aab}}$ & $61.80 \pm 1.495^{\mathrm{Aab}}$ & $60.40 \pm 0.589^{\mathrm{Ab}}$ & $55.44 \pm 1.125^{\mathrm{Ac}}$ \\
\hline \multicolumn{5}{c}{$\mathrm{a}^{*}$} \\
\hline Treatment 1 & $7.46 \pm 0.055^{\mathrm{Aa}}$ & $6.64 \pm 0.092^{\mathrm{Ab}}$ & $6.56 \pm 0.070^{\mathrm{Ab}}$ & $5.71 \pm 0.055^{\mathrm{Ac}}$ & $5.27 \pm 0.050^{\mathrm{Ad}}$ \\
Treatment 2 & $6.73 \pm 0.090^{\mathrm{Ba}}$ & $6.57 \pm 0.071^{\mathrm{Aa}}$ & $6.54 \pm 0.362^{\mathrm{Aa}}$ & $5.62 \pm 0.282^{\mathrm{Ab}}$ & $5.32 \pm 0.025^{\mathrm{Ab}}$ \\
Treatment 3 & $5.56 \pm 0.036^{\mathrm{Ca}}$ & $5.10 \pm 0.277^{\mathrm{Bab}}$ & $5.02 \pm 0.119^{\mathrm{Bab}}$ & $4.83 \pm 0.150^{\mathrm{Bb}}$ & $4.65 \pm 0.404^{\mathrm{Bb}}$ \\
\hline & & $\mathrm{b}^{*}$ & & \\
\hline Treatment 1 & $28.03 \pm 0.038^{\mathrm{Ba}}$ & $26.83 \pm 0.636^{\mathrm{Cb}}$ & $26.21 \pm 0.170^{\mathrm{Cbc}}$ & $25.64 \pm 0.223^{\mathrm{Cc}}$ & $23.61 \pm 0.478^{\mathrm{Cd}}$ \\
Treatment 2 & $37.38 \pm 0.310^{\mathrm{Aa}}$ & $32.47 \pm 0.291^{\mathrm{Bb}}$ & $31.13 \pm 0.085^{\mathrm{Bc}}$ & $31.22 \pm 0.810^{\mathrm{Bc}}$ & $29.28 \pm 0.453^{\mathrm{Bd}}$ \\
Treatment 3 & $37.38 \pm 0.310^{\mathrm{Aa}}$ & $36.25 \pm 0.111^{\mathrm{Aab}}$ & $36.15 \pm 0.986^{\mathrm{Aab}}$ & $35.50 \pm 0.297^{\mathrm{Ab}}$ & $32.18 \pm 0.348^{\mathrm{Ac}}$ \\
\hline
\end{tabular}

Values are presented as mean \pm standard deviation. Values with lowercase superscript within the same row indicate significant difference at $\mathrm{P}<0.05$ while values with uppercase superscript within the same column indicate significant difference at $\mathrm{P}<0.05$.

decreased colour $\left(\mathrm{L}^{*}, \mathrm{a}^{*}, \mathrm{~b}^{*}\right)$ could be caused by the formation of brown pigment from the Maillard reaction (Aslanova et al., 2010). Treatment two showed the best colour results and browning index that might be due to the addition of ascorbic acid during blanching the banana slices. Ascorbic acid is able to reduce quinones to phenolic compounds before they can undergo further reaction to form pigments (Laurila et al., 1998). The effectiveness of ascorbic acid in reducing browning can be found in the research by Yildiz, (2018), where different chemical agents on the prevention of enzymatic browning in banana were studied. The result showed that ascorbic acid-treated banana showed a significantly high L* value than other chemical agents during the two weeks of storage.

\subsection{Browning index}

The browning index of banana jam decreased significantly for treatment one and treatment two, while the browning index for treatment three decreased but not significantly (Table 1). The maximum value of the browning index was observed for treatment two (15.09) and the minimum value was observed for treatment three (11.67). This result was supported by Palou et al. (1999), where the browning index of banana puree decreased. In contrast, Kimura et al. (1994), reported the increased value of the browning index in a pressured jam during storage. The browning index indicates the browning reaction that occurs in a jam. The best browning index is shown by treatment three, followed by treatment two and treatment one. Treatment three showed the lowest value of the browning index, however, the value was not statistically significant. The low value of the browning index indicates less of a browning reaction than others. This result could be due to the addition of ascorbic acid, as mentioned in colour result before.

\subsection{Textural properties}

The textural properties of banana jam for all treatments increased significantly during storage (Table 3). However, the findings are not consistent with previous studies which reported decreased in textural properties. Kanwale et al. (2017) reported the texture of guava jam was gradually decrease in firmness along the storage period. In addition, Rababah et al. (2011) also observed similar findings, where the firmness of the strawberry jam decreases during storage. There are several reasons that cause the decrease in the firmness of the jam, such as acid or base-catalyzed depolymerization of pectin at high temperature and softening or cell wall degradation due to the cross-linking between carboxyl groups of adjacent polyuronide chains via calcium ions made the cell wall less accessible to enzymes (Rababah et al., 2011; Kanwale et al., 2017). The difference in our result might be due to the type of fruit used which was banana. The banana used was fully ripe that might contain a high value of pectin. Based on Tapre and Jain, (2012), the pectin content increased significantly during the ripening process due to the expense of protopectin.

\subsubsection{Effect of pH on firmness}

Firmness increased as the $\mathrm{pH}$ decreased in the banana jam. The result contrasted with the findings by Basu and Shivare, (2010), where the firmness decreased with increment of $\mathrm{pH}$ of mango jam. The authors agreed the numbers of $\mathrm{H}^{+}$ions affected the $\mathrm{pH}$ value of the jam. The $\mathrm{H}^{+}$ions replaced the methyl groups from pectin and increased the acidity and reduced the inter-chain repulsion. The binding of pectin with sugar become easy, produced the denser network formation and resulted in increased firmness of the jam. Figure 1, it is showed the $\mathrm{pH}$ value and firmness of the banana jam for all treatments had a strong correlation with the firmness and 
Table 3. Textural properties (firmness, work of shear, stickiness, work of adhesion) of banana jam during storage

\begin{tabular}{|c|c|c|c|c|c|}
\hline Day & 1 & 15 & 30 & 45 & 60 \\
\hline \multicolumn{6}{|c|}{ Firmness $(\mathrm{g})$} \\
\hline Treatment 1 & $170.00 \pm 24.60^{\mathrm{Ab}}$ & $182.41 \pm 10.50^{\mathrm{Ab}}$ & $185.24 \pm 8.37^{\mathrm{Ab}}$ & $198.39 \pm 2.62^{\text {Aab }}$ & $239.50 \pm 29.66^{\mathrm{Aa}}$ \\
\hline Treatment 2 & $165.02 \pm 25.83^{\mathrm{Ab}}$ & $184.04 \pm 4.00^{\mathrm{Aab}}$ & $188.23 \pm 5.98^{\mathrm{Aab}}$ & $197.91 \pm 7.72^{\text {Aab }}$ & $213.84 \pm 19.63^{\mathrm{Aa}}$ \\
\hline Treatment 3 & $104.72 \pm 5.11^{\mathrm{Bd}}$ & $107.93 \pm 17.57^{\mathrm{Bcd}}$ & $130.98 \pm 3.21^{\mathrm{Bbc}}$ & $147.39 \pm 6.36^{\mathrm{Bab}}$ & $160.08 \pm 5.22^{\mathrm{Ba}}$ \\
\hline \multicolumn{6}{|c|}{ Work of shear (g.sec) } \\
\hline Treatment 1 & $480.60 \pm 5.89^{\mathrm{Ac}}$ & $479.37 \pm 25.23^{\mathrm{Ac}}$ & $505.86 \pm 56.79^{\mathrm{Abc}}$ & $573.4 \pm 20.96^{\mathrm{Aab}}$ & $625.65 \pm 34.36^{\mathrm{Aa}}$ \\
\hline Treatment 2 & $477.88 \pm 2.09^{\mathrm{Ab}}$ & $478.93 \pm 75.85^{\mathrm{Ab}}$ & $532.31 \pm 28.94^{\text {Aab }}$ & $581.27 \pm 30.08^{\text {Aab }}$ & $616.66 \pm 39.52^{\mathrm{Aa}}$ \\
\hline Treatment 3 & $283.85 \pm 31.85^{\mathrm{Bb}}$ & $285.48 \pm 71.37^{\mathrm{Bb}}$ & $377.97 \pm 11.06^{\mathrm{Bab}}$ & $415.74 \pm 5.85^{\mathrm{Ba}}$ & $472.55 \pm 14.70^{\mathrm{Ba}}$ \\
\hline \multicolumn{6}{|c|}{ Stickiness $(\mathrm{g})$} \\
\hline Treatment 1 & $-55.52 \pm-3.809^{\mathrm{Ba}}$ & $-60.74 \pm-0.871^{\text {Bab }}$ & $-65.50 \pm-2.331^{\text {Cac }}$ & $-68.03 \pm-1.833^{\mathrm{Bc}}$ & $-69.86 \pm-0.160^{\mathrm{Bc}}$ \\
\hline Treatment 2 & $-48.28 \pm-4.460^{\mathrm{Ba}}$ & $-55.25 \pm-3.475^{\mathrm{Ba}}$ & $-55.87 \pm-1.755^{\mathrm{Ba}}$ & $-58.29 \pm-6.945^{\mathrm{Ba}}$ & $-60.02 \pm-5.320^{\mathrm{Aa}}$ \\
\hline Treatment 3 & $-36.44 \pm-2.930^{\mathrm{Aa}}$ & $-36.63 \pm-3.094^{\mathrm{Aa}}$ & $-41.02 \pm-2.070^{\mathrm{Aab}}$ & $-45.94 \pm-0.187^{\mathrm{Ab}}$ & $-53.93 \pm-2.631^{\mathrm{Ac}}$ \\
\hline \multicolumn{6}{|c|}{ Work of adhesion (g.sec) } \\
\hline Treatment 1 & $-85.00 \pm-5.31^{\mathrm{Ba}}$ & $-89.75 \pm-2.19^{\mathrm{Bab}}$ & $-96.08 \pm-1.54^{\text {Babc }}$ & $-102.32 \pm-4.99^{\mathrm{Bbc}}$ & $-111.5 \pm-11.24^{\mathrm{Ac}}$ \\
\hline Treatment 2 & $-79.50 \pm-5.03^{\mathrm{Ba}}$ & $-93.58 \pm-7.79^{\mathrm{Ba}}$ & $-96.08 \pm-5.51^{\mathrm{Ba}}$ & $-97.6 \pm-2.54^{\mathrm{Ba}}$ & $-98.24 \pm-18.85^{\mathrm{Aa}}$ \\
\hline Treatment 3 & $-61.75 \pm-4.785^{\mathrm{Aa}}$ & $-64.12 \pm-1.040^{\mathrm{Aa}}$ & $-67.65 \pm-4.785^{\mathrm{Aab}}$ & $-76.10 \pm-4.845^{\mathrm{Ab}}$ & $-94.52 \pm-3.816^{\mathrm{Ac}}$ \\
\hline
\end{tabular}

Values are presented as mean \pm standard deviation. Values with lowercase superscript within the same row indicate significant difference at $\mathrm{P}<0.05$ while values with uppercase superscript within the same column indicate significant difference at $\mathrm{P}<0.05$.

the Pearson's correlation have a significant difference $(\mathrm{P}<0.05)$.

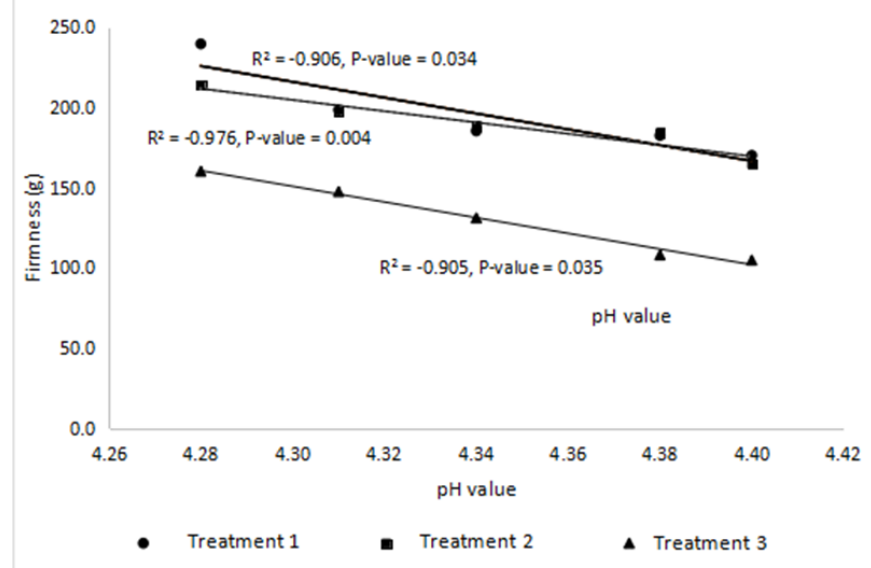

Figure 1. Effect of $\mathrm{pH}$ on firmness of banana jam during storage

\subsubsection{Effect of total soluble solids on firmness}

The firmness increased together with the total soluble solids along the storage period. Basu and Shivhare, (2010) observed a similar trend, where the firmness of mango jam increased with sugar concentration. According to Evageliou et al. (2000), the equilibrium between water and pectin was disturbed by sugar that acts as a dehydrating agent. Increased total soluble solids reduced the chance of forming hydrogen bonds due to the reduction of water available in pectinsugar-acid mixed (Evageliou et al., 2000; Bayarri et al., 2004). The correlation between total soluble solids and firmness can be observed in Figure 2. It is shown that all treatments have a strong correlation between total soluble solids and firmness with Pearson's correlation with significant difference $(\mathrm{P}<0.05)$.

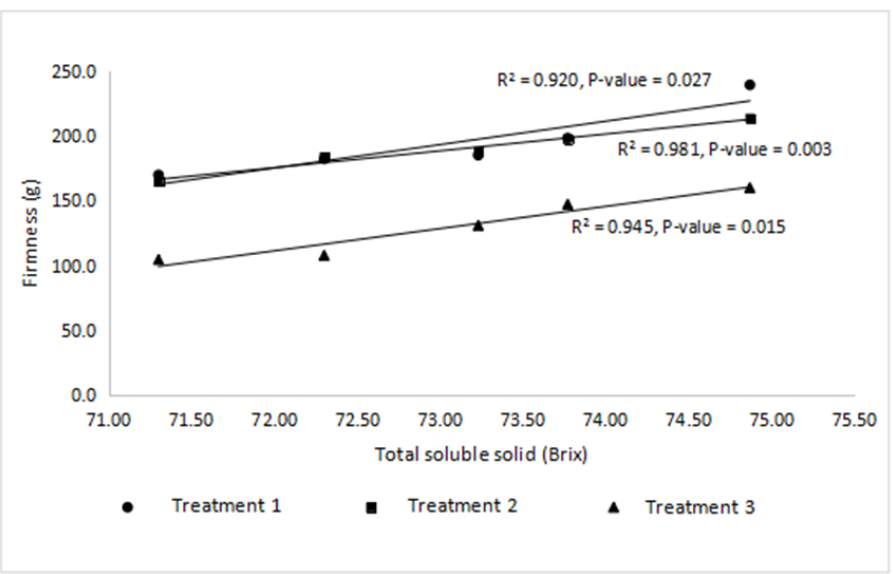

Figure 2. Effect of total soluble solids on firmness of banana jam during storage

\section{Conclusion}

$1.5 \%$ of ascorbic acid and $0.1 \%$ of sodium metabisulphite were used in this study. Both are able to reduce the browning reaction in the banana jam during storage. Hot water blanching was applied during the preparation of the sample, able to inhibit the enzyme activity in banana slices and prevent browning reaction. The $\mathrm{pH}$ value, total soluble solids, colour, browning index and textural properties have significant $(\mathrm{p}<0.05)$ differences during storage, except titrable acidity. Therefore, treatment three was the best treatment in this study. 


\section{Conflict of interest}

The authors declare no conflicts of interest.

\section{Acknowledgement}

The authors would like to thank Universiti Putra Malaysia (UPM) and the Faculty of Food Science and Technology (UPM) for the facilities rendered.

\section{References}

Ahmed, I., Khan, M.U., Qazi, I.M., Ullah, S.U., Khan, A. and Jamal, S. (2015). Development and quality evaluation of banana mushroom blended jam. Biological Sciences-PJSIR, 60(1), 11-18. https:// doi.org/10.52763/PJSIR.BIOL.SCI.60.1.2017.11.18

Aksay, S., Tokbaş, H., Arslan, R. and Çınar, F. (2018). Some physicochemical properties of the whole fruit mandarin jam. Turkish Journal of Agriculture-Food Science and Technology, 6(5), 632-635. https:// doi.org/10.24925/turjaf.v6i5.632-635.1948

Arpita, S., Subroto, D., Pinaki, B. and Bidyut, B. (2010). Inhibition of polyphenol oxidase in banana, apple and mushroom by using different anti-browning agents under different conditions. International Journal of Chemistry Science, 8(5), 550-558.

Ashaye, O.A. and Adeleke, T.O. (2009). Quality attributes of stored Roselle jam. International Food Research Journal, 16(3), 363-371.

Aslanova, D., Bakkalbasi, E. and Artik, N. (2010). Effect of storage on 5-hydroxymethylfurfural (HMF) formation and color change in jams. International Journal of Food Properties, 13(4), 904-912. https:// doi.org/10.1080/10942910902908896

Ayub, M., Ullah, J., Ali, M. and Zeb, A. (2010). Evaluation of strawberry juice preserved with chemical preservatives at refrigeration temperature. International Journal of Nutrition and Metabolism, 2 (2), 27-32.

Banaś, A., Korus, A. and Korus, J. (2018). Texture, color, and sensory features of low-sugar gooseberry jams enriched with plant ingredients with pro-health properties. Journal of Food Quality, 25(3),100-115. https://doi.org/10.1155/2018/1646894

Basu, S. and Shivhare, U.S. (2010). Rheological, textural, micro-structural and sensory properties of mango jam. Journal of Food Engineering, 100(2), 357-365.

j.jfoodeng.2010.04.022

Bayarri, S., Duran, L. and Costell, E. (2004). Influence of sweeteners on the viscoelasticity of hydrocolloids gelled systems. Food Hydrocolloids, 18(4), 611-619. https://doi.org/10.1016/j.foodhyd.2003.10.004

Codex Alimentarius Commission. (2004). Distribution of the report of the $22 \mathrm{nd}$

session of the codex committee on processed fruits and vegetables (Alinorm 03/27). Retrieved from http://www.fao.org/ tempref/codex/Meetings/CCPFV/ccpfv22/ pf22_02e.pdf

Danyen, S.B., Boodia, N. and Ruggoo, A. (2009). Interaction effects between ascorbic acid and calcium chloride in minimizing browning of freshcut green banana slices. Journal of Food Processing and Preservation, 33(S1), 12-26. https:// doi.org/10.1111/j.1745-4549.2008.00246.x

Darkwa, I. and Boakye, N.A.B. (2016). The Preparation of Jam: Using Star Fruit. Global Journal of Educational Studies, 2(2), 2377-3936.

de Souza Viana, E., de Jesus, J.L., Reis, R.C., de Andrade, M.V.S. and do Sacramento, C.K. (2014). Physicochemical and sensory characterization of banana and araçá-boi jam. Food and Nutrition Sciences, 5(8), 733-741. https://doi.org/10.4236/ fns.2014.58083

Ding, P. and Ling, Y.S. (2014). Browning assessment methods and polyphenol oxidase in UV-C irradiated Berangan banana fruit. International Food Research Journal, 21(4), 1667-1674.

Ehsan, E.B., Naeem, Z.P., Ghafoor, A. and Bahtti, M.S. (2002). Development, standardization and storage studies on watermelon lemon jam. Pakistan Journal of Food Sciences, 12(3-4), 21-24

Evageliou, V., Richardson, R.K. and Morris, E.R. (2000). Effect of $\mathrm{pH}$, sugar type and thermal annealing on high-methoxy pectin gels. Carbohydrate Polymers, 42(3), 245-259. https:// doi.org/10.1016/S0144-8617(99)00191-5

Food and Agriculture Organization (FAO). (2019). Fruit sugar preserves technology: jams, jellies, marmalade, fruit paste. Retrieved on 9 December, 2019 from FAO Website: http://www.fao.org/input/ download/standards/11254/CXS_296e.pdf

Hussain, I. and Shakir, I. (2010). Chemical and organoleptic characteristics of jam prepared from indigenous varieties of apricot and apple. World Journal of Diary and Food Sciences, 5(1), 73-78.

Kanwale, N., Randhawa, M.A. and Iqbal, Z. (2017). Influence of processing methods and storage on physico-chemical and antioxidant properties of guava jam. International Food Research Journal, 24 (5), 2017-2027.

Khan, R.U., Afridi, S.R., Ilyas, M., Sohail, M. and Abid, H. (2012). Development of strawberry jam and its quality evaluation during storage. Pakistan Journal of Biochemistry and Molecular Biology, 45(1), 2325.

Khan, U., Ullah, J., Saeed, B. and Ali, F. (2014). Effect 
of potassium sorbate and sodium benzoate on the quality and shelf-life of strawberry jam during storage. Journals of Agricultural and Biological Sciences, 9(12), 454-458.

Kheng, T.Y., Ding, P. and Abdul Rahman, N.A. (2012). Determination of optimum harvest maturity and physico-chemical quality of Rastali banana (Musa AAB Rastali) during fruit ripening. Journal of the Science of Food and Agriculture, 92(1), 171-176. https://doi.org/10.1002/jsfa.4559

Kimura, K., Ida, M., Yosida, Y., Ohki, K., Fukumoto, T. and Sakui, N. (1994). Comparison of keeping quality between pressure-processed jam and heat-processed jam: changes in flavor components, hue, and nutrients during storage. Bioscience, Biotechnology, and Biochemistry Journal, 58(8), 1386-1391. https:// doi.org/10.1271/bbb.58.1386

Laurila, E., Kervinen, R. and Ahvenainen, R. (1998). The inhibition of enzymatic browning in minimally processed vegetables and fruits. Postharvest News and Information, 9(4), 53-66.

Makanjuola, O.M. and Alokun, O.A. (2019). Microbial and physicochemical properties of date jam with inclusion of apple and orange fruits. International Journal of Food Science and Nutrition, 4(3), 102106.

Martínez, M.C., Corzo, N., Villamiel, M. and Castillo, M.D. (2012). Browning reactions. Food Biochemistry and Food Processing, $2^{\text {nd }}$ ed. United Kingdom: John Wiley and Sons. https:// doi.org/10.1002/9781118308035.ch4

Muresan, C., Pop, A., Muste, S., Scrob, S. and Rat, A. (2014). Study concerning the quality of jam products based on banana and ginger. Journal of Agroalimentary Processes and Technologies, 20(4), 408-411.

Ngoh, N., Njapndounke, B., Tembe, T., Nkouandou, M., Ngombi, N., Kendine, V.C., Manjia, N.S.U. and Zambou, N.F. (2018). Optimization of process conditions for jam production from plantain-like hybrid (CARBAP K74) grown in two agroecological zones of Cameroon. International Journal of Agricultural Policy and Research, 6(4), 50-63.

Palou, E., López-Malo, A., Barbosa-Cánovas, G.V., Welti-Chanes, J. and Swanson, B.G. (1999). Polyphenoloxidase activity and color of blanched and high hydrostatic pressure treated banana puree. Journal of Food Science, 64(1), 42-45. https:// doi.org/10.1111/j.1365-2621.1999.tb09857.x

Patel, N.V., Naik, A.G. and Senapati, A.K. (2015). Quality Evaluation and Storage Study of Banana Pineapple Blended Jam. International Journal Food Quality and Safety, 3(1), 7-14.
Pavlova, V., Karakashova, L., Stamatovska, V., Delchev, N., Necinova, L., Nakov, G., Menkinoska, M. and Blazevska, T. (2013). Storage impact on the quality of raspberry and peach jams. Journal of Hygienic Engineering and Design, 664, 25-28.

Rababah, T.M., Al-Mahasneh, M.A., Kilani, I., Yang, W., Alhamad, M.N., Ereifej, K. and Al-u'datt, M. (2010). Effect of jam processing and storage on total phenolics, antioxidant activity, and anthocyanins of different fruits. Journal of the Science of Food and Agriculture, 91(6), 1096-1102. https:// doi.org/10.1002/jsfa.4289

Sawant, A.A. and Patil, M.M. (2013). Preparation of guava jam blended with sapota. Agricultural Engineering International: CIGR Journal, 15(1), 167-172.

Shah, W., Khan, A., Zeb, A., Khan, M.A., Shah, F.N., Amin, N.U., Ayub, M., Wahab, S., Muhammad, A. and Khan, S.H. (2015). Quality evaluation and preparation of apple and olive fruit blended jam. Global Journal Medical Research: L Nutrition and Food Science, 15(1), 15-21.

Shakir, I., Durrani, Y., Hussain, I., Qazi, I.M. and Zeb, A. (2008). Physicochemical analysis of apple and pear mixed fruit jam prepared from varieties grown in Azad Jammu and Kashmir. Pakistan Journal Nutrition, 7(1), 177-180. https://doi.org/10.3923/ pjn.2008.177.180

Tapre, A.R. and Jain, R.K. (2012). Study of advanced maturity stages of banana. International Journal of Advanced Engineering Research and Studies, 1(3), 272-274.

Touati, N., Tarazona-Díaz, M.P., Encarna, A.E. and Louaileche, H. (2014). Effect of storage time and temperature on the physicochemical and sensory characteristics of commercial apricot jam. Food Chemistry, 145, 23-27. https://doi.org/10.1016/ j.foodchem.2013.08.037

Wang, S., Lin, T., Man, G., Li, H., Zhao, L., Wu, J. and Liao, X. (2013). Effects of anti-browning combinations of ascorbic acid, citric acid, nitrogen and carbon dioxide on the quality of banana smoothies. Food and Bioprocess Technology, 7(1), 161-173. https://doi.org/10.1007/s11947-013-1107-7

Yap, M., Fernando, W.M., Brennan, C.S., Jayasena, V. and Coorey, R. (2017). The effects of banana ripeness on quality indices for puree production. LWT - Food Science and Technology, 80, 10-18. https://doi.org/10.1016/j.lwt.2017.01.073

Yildiz, G. (2018). The effect of different chemical agents on the prevention of enzymatic browning in banana. Journal of Food Science and Engineering, 7, 91-96. 